\title{
A Case of Systemic Lupus Erythematosus that Healed Completely after Repeated Intradermal Injections with a Non-Specific Antigen Preparation
}

\author{
Kimihiko Okazaki* \\ Okazaki Medical Clinic, Japan \\ Submission: September 18, 2017; Published: September 21, 2017 \\ *Corresponding author: Kimihiko Okazaki, Okazaki Medical Clinic, Ukyoku Kyoto, Japan, Email: ma13081x@ma1.seikyou.ne.jp
}

\section{Introduction}

It is well established that the etiology of allergic diseases is that combinations of mast cells and allergen-specific antibodies cause allergic symptoms when the patients meet allergens. Similarly, the etiology of auto-immune diseases is that combinations of cytolytic T lymphocytes and organ-specific antibodies cause injury of the organ. A most plain idea would be that break down of the above mentioned combinations must bring about disappearance of causes of the diseases. It seems to me that few, if any, contemporary Immunologists have such concepts. To work out the above mentioned concept, it is necessary to have the patients make non-specific antibodies by themselves. In order for the patients to do so, they need to receive intradermal injections with non-specific antigen preparations. Consequently, non-specific antibodies accumulate in the patients' bodies, which may replace specific antibodies from respective cells bringing about elimination of causes of the diseases. Needless to mention, where there is no cause, there is no disease. Details are demonstrated elsewhere [1]. A possible alternative opinion may be transfusion with gamma-globulin solution. However, it is dangerous because anti-gamma-globulin antibodies may be produced in the recipient's body, which could cause an anaphylactic reaction after a large number of infusions.
Case

A 64-year-old woman (M.0.) visited my clinic on April 21, 2011. She told me that she had had a systemic urticaria with conjunctivitis and rhinitis in middle of May, 1987. She was diagnosed as systemic lupus erythematosus by a doctor in The Osaka Medical School Hospital after examination of her bone marrow in June, 1987. She received $40 \mathrm{mg}$ daily of oral prednisolon for 3 months, $10 \mathrm{mg}$ daily for $1 \mathrm{month}$, and $5 \mathrm{mg}$ daily continuously. I intradermally injected her at her upper-arms with $0.1 \mathrm{ml}$ of $1,000,000$ fold with saline diluted Neurotropin; a product of Nippon Zohki Pharmaceutical Company (Osaka), consisting of an extract of rabbit skin inflamed by inoculation of Vaccinia virus, at 2 19 day intervals during the period from April 21, 2011 until August 25, 2011. The total number of injections was 18. She is enjoying a healthy life as of September 16, 2017.

\section{Reference}

1. Okazaki K (2009) Therapeutic significance of non-specific antigens as anti-allergic and anti-autoimmune agents. Pharmacometrics 76(5/6): 105-107.

\begin{tabular}{l} 
Your next submission with Juniper Publishers \\
will reach you the below assets \\
- Quality Editorial service \\
- Swift Peer Review \\
- Reprints availability \\
- E-prints Service \\
- Manuscript Podcast for convenient understanding \\
- Global attainment for your research \\
- Manuscript accessibility in different formats \\
( Pdf, E-pub, Full Text, Audio) \\
- Unceasing customer service \\
Track the below URL for one-step submission \\
https://juniperpublishers.com/online-submission.php \\
\hline
\end{tabular}

